EDUKACJA MIĘDZYKULTUROWA

2015, nr 4

ISSN 2299-4106

Dorota MisiejuK

\title{
„Społeczeństwa wielokulturowe - dynamika, zmienność i nieprzewidywalność. Ku jakim strategiom w edukacji międzykulturowej?”
}

\section{Białystok-Lipowy Most, 25-28 maja 2014 roku}

Katedra Edukacji Międzykulturowej działająca na Wydziale Pedagogiki i Psychologii Uniwersytetu w Białymstoku, we współpracy ze Stowarzyszeniem Wspierania Edukacji Międzykulturowej, po raz kolejny podjęła trud zorganizowania debaty o wielokulturowości. Konferencja została objęta Honorowym Patronatem J.M. Rektora Uniwersytetu w Białymstoku oraz Komitetu Nauk Pedagogicznych PAN, a także Wojewody Podlaskiego. Tegoroczna konferencja, która odbyła się w dniach 25-28 maja 2014 roku, miała hasło: Społeczeństwa wielokulturowe - dynamika, zmienność i nieprzewidywalność. Ku jakim strategiom w edukacji międzykulturowej?

Tradycyjnie organizatorzy założyli wielodyscyplinarność jako fundament oglądu problematyki, oraz problemowość jako strategie debaty. Formuła konferencji umożliwiała zarówno prezentacje koncepcji i wyników badań oraz prezentacje rozwiązań diagnostycznych i metodycznych odnoszących się do dynamiki społeczeństw wielokulturowych.

Problematyczność spotkania opierała się na osiowych pytaniach dotyczących dylematów współczesnych społeczeństw z ambicją konstruowania wielokulturowości jako standardu stosunków międzygrupowych i międzyosobowych. Zastanawiano się nad konsekwencjami polityki asymilacji i akulturacji, debatując o normach społecznych, relacjach społecznych grup mniejszościowych i większościowych oraz kategorii obywatelstwa. Podjęto także rozważania o wspólnotach, zarówno tych tradycyjnych dla określonych obszarów geograficznych, wspólnotach z biografia imigrancką, jak i tych tworzonych obecnie o ambicjach wspólnoty cywilizacyjnej: Europejczyków.

W trakcie prezentacji można było usłyszeć, jak również zobaczyć, gdyż wykładom zasadniczo towarzyszyły prezentacje multimedialne przykłady dobrych praktyk w szkole i różnorodnych instytucjach edukacji nieformalnej, 
które realizowały założenia i cele edukacji międzykulturowej. Obraz owych dobrych praktyk i następujące po nich debaty pozwoliły uczestnikom konferencji na określanie strategii edukacyjnych w tym zakresie. Pozwoliły też na debatę o powinnościach szkoły i podmiotów edukacji nieformalnej w społeczeństwach wielokulturowych. Wytworzyło się swoiste środowisko dyskusji myślenia krytycznego wobec funkcjonujących mitów edukacyjnych.

Specjalne miejsce w dyskusjach i debatach oddano kategorii pogranicza. Rozumiano ją przede wszystkim jako przestrzeń wielu tradycji kulturowych współegzystujących w przestrzeni socjalizacji jednostek. W perspektywie wielokulturowości, rozumianej jako wartość i zasada współżycia społecznego, wymaga od pedagogów przemyśleń na temat kształtowania standardu społecznych relacji oraz przemyślenia prezentacji treści edukacyjnych. Odwołując się do teoretycznych uwarunkowań komunikacji, wskazywano na potrzebę zmian w zakresie założeń komunikacyjnych i form komunikowania (się), aby poszukiwać systemu czy modelu, który określi pole zaangażowania systemu edukacji i wychowania w ramach kultury współczesnej.

Tak nakreślony obszar rozważań zgromadził grono badaczy, jak i praktyków. Obecność, poprzez wystąpienia swoich pracowników, zaznaczyły takie ośrodki uniwersyteckie w Polsce jak Cieszyński Ośrodek Uniwersytetu Śląskiego, Ośrodek warszawski, reprezentowany zarówno przez Akademię Pedagogiki Specjalnej, Uniwersytet Warszawski oraz Szkołę Główną Gospodarstwa Wiejskiego, Uniwersytet Marii Curie Skłodowskiej, Uniwersytet w Toruniu, Krakowie, Uniwersytet w Olsztynie, Uniwersytet Wrocławski. Obecni byli także goście zagraniczni z Białorusi, Niemiec, Rosji.

XII Międzynarodowa Konferencja była też okazją odznaczenia historii Katedry Edukacji Międzykulturowej, która na Wydziale Pedagogiki i Psychologii istnieje od 20 lat. Od samego początku jej istnienia kierownikiem jest prof. dr hab. Jerzy Nikitorowicz, który wraz z Zespołem analizuje teorie, rozwija idee, diagnozuje i poszukuje rozwiązań problemów kulturowej tożsamości zbiorowych i indywidualnych w warunkach współczesnej kultury. Edukacja międzykulturowa i jej pole problematyki definiowane jest w polskiej pedagogice od lat 90. XX wieku. Niewątpliwie do rozwoju dyscypliny przyczyniło się wiele inicjatyw wspólnych, jak utworzony przez prof. dr. hab. Tadeusza Lewowickiego wspólnie z prof. dr. hab. Jerzym Nikitorowiczem, Społeczny Zespół Badań nad Pograniczem, czy współpraca z Uniwersytetem Mikołaja Kopernika w Toruniu, firmowana osobą prof. dr. hab. Piotra Petrykowskiego, oraz Uniwersytetem M. Curie-Skłodowskiej w Lublinie, gdzie pracuje prof. dr 
hab. Dariusz Kubinowski. Katedra ma też bliskie związki z ośrodkiem warszawskim, przede wszystkim poprzez kontakty z prof. dr. hab. Tadeuszem Pilchem, prof. dr. hab. Markiem Konopczyńskim czy prof. dr hab. Krystyną Błeszyńską. 20 lat aktywności badawczej, dydaktycznej i inicjatyw społecznych, podejmowanych w imię idei wielokulturowości i rozwijania edukacji międzykulturowej, dało efekty w postaci indywidualnych osiągnięć badaczy. Swoisty status liderów w kształtowaniu obrazu problematyki edukacji międzykulturowej osiągnęli badacze ośrodka białostockiego dr hab. Mirosław Sobecki prof. UwB, dr hab. Dorota Misiejuk; ośrodka cieszyńskiego dr hab. Ewa Ogrodzka-Mazur, prof. UŚ, dr hab. Alina Szczurek-Boruta, prof. UŚ, dr hab. Barbara Grabowska.

Hasłem przewodnim prac konferencji była współpraca, współdziałanie teorii z praktyką, a swoistym efektem tych założeń - otwieranie nowych pograniczy w debacie o kondycji edukacji międzykulturowej. Obrady otworzyli kierownik Katedry Edukacji Międzykulturowej prof. zw. dr hab. Jerzy Nikitorowicz i dziekan Wydziału Pedagogiki i Psychologii dr hab. Mirosław Sobecki prof. UwB. Słowo wstępu miał także prorektor Uniwersytetu w Białymstoku dr hab. Jerzy Halicki. Potem rozpoczęły się obrady w sesji plenarnej. Drugiego dnia debaty odbywały się zarówno w formie obrad planarnych, jak i sekcjach tematycznych. Przewidziane tematyczne sekcje to: tożsamość kulturowa, diagnoza środowisk wychowawczych, komunikacja międzykulturowa oraz transmisja kultury.

W sekcji poświęconej problematyce tożsamości kulturowej ujmowano ją w perspektywie zmiany kulturowej, zmiany społecznej, a także rozwoju jednostki - w perspektywie zakotwiczenia w tradycji. W sekcji poświęconej problematyce diagnozowania obrady skoncentrowały się wokół wyzwań diagnozy pedagogicznej w kontekście różnorodności standardów kulturowo-społecznych, kontekstów lokalnego standardu społecznego oraz zmienności i płynności kategorii oceny. Sekcja o komunikacji międzykulturowej podjęła zagadnienie kontaktu międzygrupowego w perspektywie różnicy kulturowej, pytano o kompetencje potrzebne jednostce w nowoczesnym świecie i nowe wyzwania w zakresie konstruujących się tożsamości zbiorowych. Wreszcie sekcja transmisja kultury pracowała nad problemem międzygeneracyjnego przekazu kultury, zmiany tradycji i efektów społecznych tych procesów.

W konsekwencji szerokich i burzliwych dyskusji dorobek konferencji będzie prezentowany w trzech tematycznie opracowanych tomach. 